\title{
地方圈域における「都市化」の空間構造
}

その 1 . 関東・東北地方の人口指標にみる地域特性

$\begin{array}{lllll}\text { 正会員 } & \text { 青 } & \text { 木 } & \text { 志 } & \text { 郎* } \\ \text { 正会員山 } & \text { 森 } & \text { 芳 } & \text { 郎** }\end{array}$

\section{1. 研究の視点亡方法}

最近の大都市の影響によって地域が変動し，「農村的 なもの」からしだいに「都市的なもの」に移行する「都 市化」現象が，しばしば注目される。地域社会のより建 設的な将来を選択するために，都市や地域の開発計画を 討議する機会が多くなっているが，その基礎的な作業と して，地域の動態分析を欠くことはできない。

本報告はこの視点に立ち, 農業地帯からいわゆる巨大 都市までを含んだ地方圈域1)における「都市化」の空間 構造を解明していこうとするものである。まず，「都市 化」を量的に，あるいは可視的に把握するために，地域 変動をあらわす指標を選択し，それを地図上に表示し， 観察する。その結果にもとづいて地方圈域における「都 市化」の秩序を見出そう。

研究の手順を整理しょう。

（1）圈域の設定 地域の変化は多くの個性を示し ている。時閒的（歴史的）経過のなかで，あるいは空間 的なひろがりのなかで，その一般性を検証することは， かならずしも容易ではない。しかしその説得性のため に, 分析圈域を拡大し, 平均值を求めるだけでは, 限定 された圈域での特性を明らかにすることがむずかしい， 地域聞の共通性とともにその相違にも注目すべきことが 忘れられがちになる。地域動熊の分析には，われわれの 生活活動圈の段階に応じた視点が欠かせないだろら。

本報告では，農業地帯から巨大都市まで含めて「都市 化」の進行を観察するために，地方圈域の段階を採用寸 る。事例対象としては関東, 東北地方の 12 都県を選定 する。世界的巨大都市東京を含み，日本でも代表的な 農業地带として東北地方があり，地形上の特質からある 程度閉じた圈域としての考察が可能だからである（図 1)。

ちなみに圈域の面積約 $99,176 \mathrm{~km}^{2}$ (1973 年, 昭 48現 在), 人口約 $42,000,000$ 人 (1975 年, 昭 50 国勢調查 結果), 人口密度 424 人 $/ \mathrm{km}^{2}$ である。南北約 $600 \mathrm{~km}$ の ひろがりをもつ。

* 東京工業大学教授 工博

** URB 研究室代表

（昭和 52 年 $10^{\circ}$ 月 1 日本稿受理 - 討論期限昭和 53 年 2 月末日）
（2）指標の選択 地域の動態すなわち「都市化」 を量的に示すのが「都市化」指標である。すべて行政庁 の公開資料から抽出した。つぎの 3 群に区分される ${ }^{2) 。}$

1. 人口に関するもの。その増減・移動・構成につい て，国勢調查の結果から抽出した。

2. 経済に関するるの。事業・商業活動・所得・財政 に注目。

3. 空間に関するもの。土地利用をあらわすものとし て, 耕地面積・地洒等を選ぶ。これ等農業関係の指 標は都市側に導かれる変動の「鏡」としてのの機能 をもっている。さらに地域動態の側面として，方之 の動き, 字の動きを鉄道と道路の利用状況から頙 在化させる。

採用統計時期は，人口に関するものが 1965 年（昭 40)～70 年 (昭 45), 経済・空間に関するものが 1970 75 年 (昭 50) と, できるだけ最近の動態を観察し, 必 要に応じてそれ以前の統計もつけ加えた。

（3）分析の単位「都市化」の地域特性分析は, 第 1 に都市部と農村部, 第 2 に中央と地方, 第 3 に幹線 沿いと支線沿いの閒の比較によってすすめた。そこで上 記の指標の分析単位として市町村を採用する。都県に属 していても, 離島は除いた。これまで都県単位での比較 が多数試みられているが, 中央と地方といら視点を満足 できても, 都市と農村, 幹線と支線の比較はあまり精密 ではない。

（4）作業の過程「都市化」指標の分析は, 統計 資料を地図上に表示し，その視覚的な観察によった。高 度な手法を駆使した厳密な結論づけりも, 研究課題に たいして久かせないのは，ひろい専閏分野からの問題の 提起であり，それには共通の研究基盤として，まず資料 を「だれにでもわかる客観的な地図」の上に現状を呈示 すべきであると考えたからである。基礎資料はだれでも 入手できる公開統計であり, 考察の過程も単純に視覚的 にすすめていこうとするものである。

指標の地図化には, 処理情報が極めて多いので, 電算 機を使用した。その手順は，1. 指標の選択，2．統計の 抽出, 3. 行政境界による網目作成, 4. 頻度分布図の作 成と階級分け，5. 電算機による地図化，6. 解析であ 


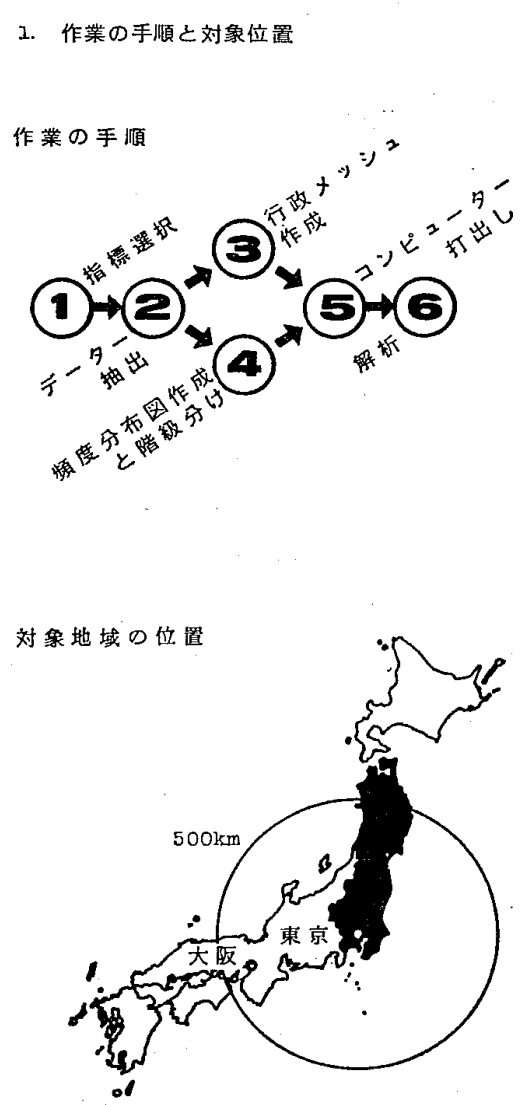

図-1

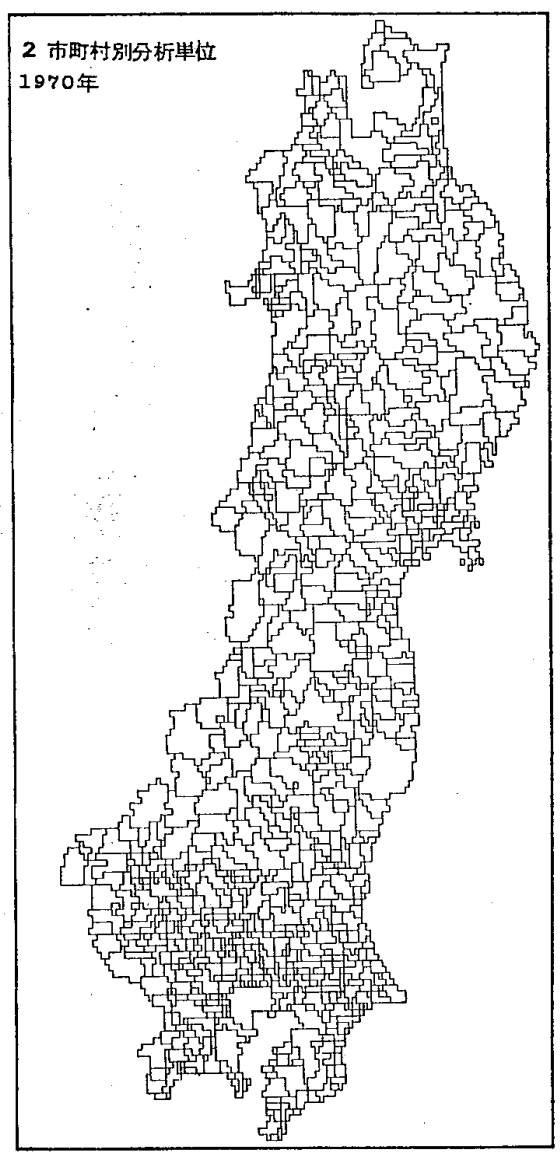

図一2

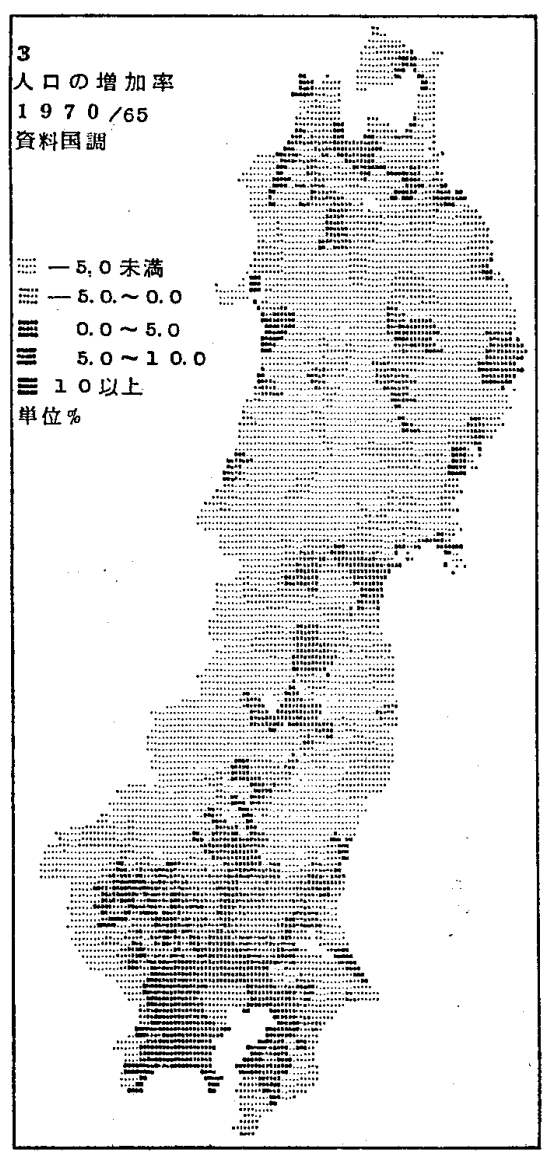

図一3

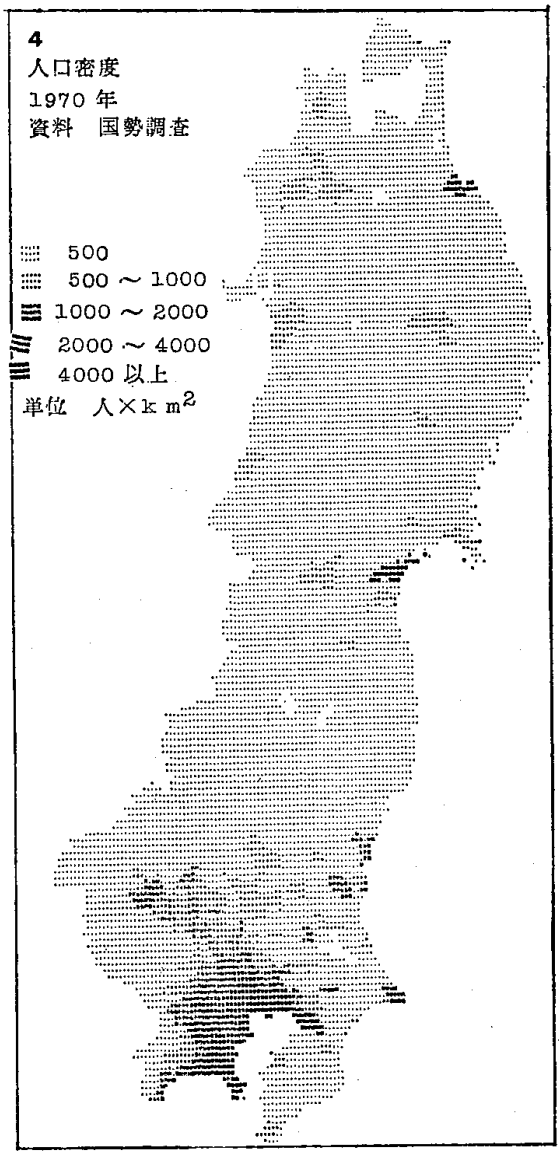

図一4

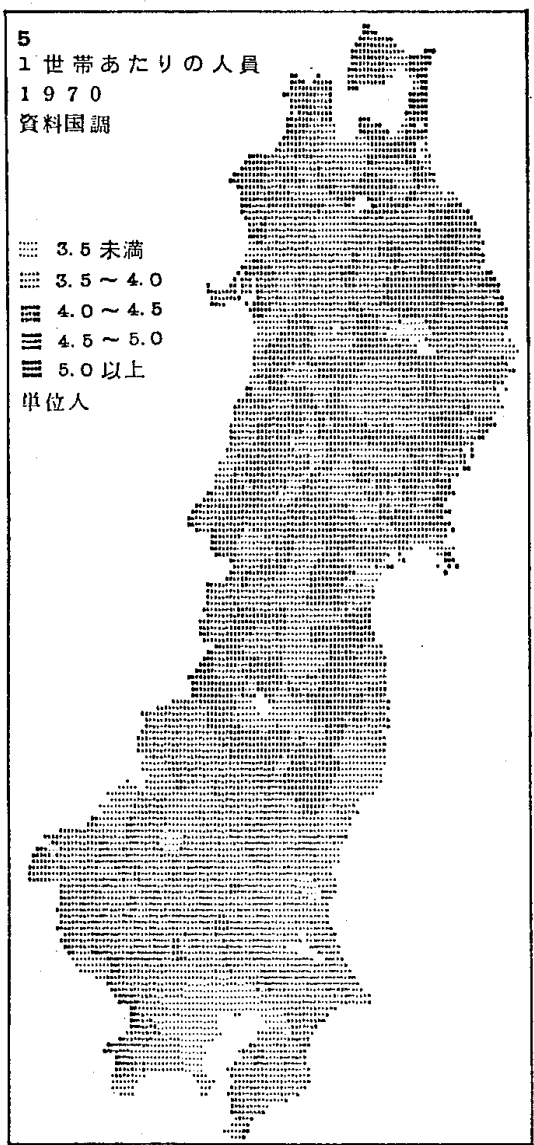

図一5

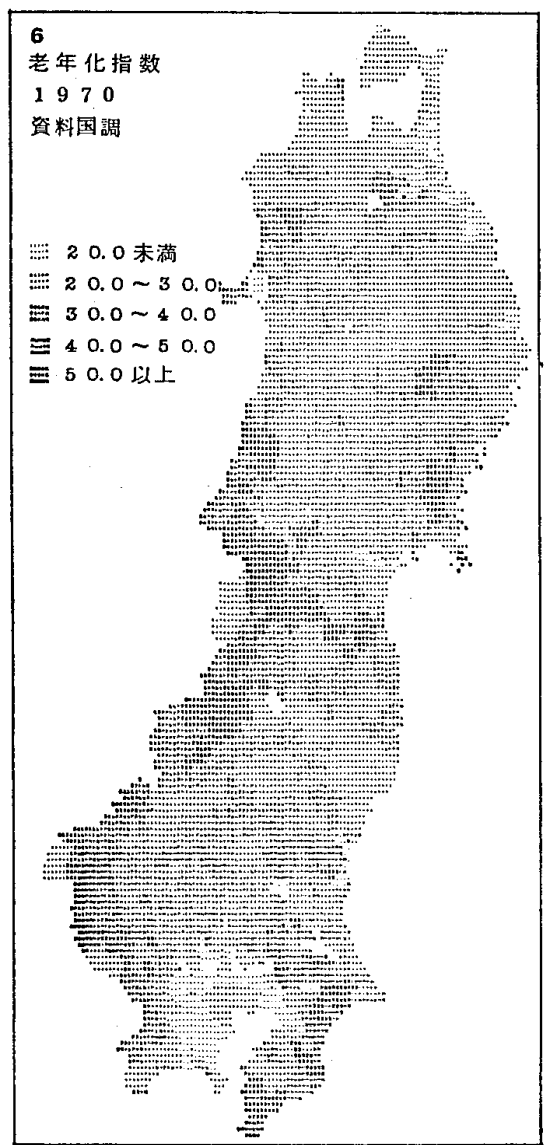

図-6 
る。資料の階級区分は 5 段階である。指標ごとの頻度分 布図上で, 全事例のうち最大・最小の極限に属するそれ ぞれ $5 \%$ を除き，残りを 5 等分に区分した（図 1 )。

本報告の構成は，第 1 報で人口指標について分析し， 第 2 報で経済・空間指標について分析をすすめ, そ忆ぞ れ地域特性解析ののち,「都市化」位相を整理していく 予定である。

\section{2. 人口指標における「都市化」}

地域の動態をもっとも端的にあらわすのが人口関係の 指標である。「都市化」に視点を置いて選定した指標は つぎの通りである。

人口増加率, 人口密度, 世带人員, 老年化指数, 人 口の移動率, 第 I 次産業人口割合, 事務・技術 - 管理 関係職業人口割合，第 1 次産業人口増加率，第 2 次産 業人口増加率, 第 3 次産業人口増加率

いずれも 1970 年 (昭 45) 国樊調查の結果を用いるも ので, 増加率等一部は 65 年（昭 40）調査との対比をみ た。分析の視点としては，都市部と農村部との比較と同 時に, 県庁の所在や工業化など，都市の性格による都市 間の差異にも注目した。すでに 75 年 (昭 50) 調查の結 果も一部公表されており，必要に応じて引用した。なお 本報告では, 紙面の都合から作業成果の地図のみを紹介 し, 引用数值全体については, 統計が公開されているこ とを前提に再掲を省いた。

（1）人口増加率（図 3 ）都市部の人口が増加し， 農村部の人口が減少している。東北 6 県（青森・岩手・ 宮城・秋田・山形・福島）の 65 70 年の人口増加率 を，市部・郡部にわけて平均すると，市部 $3.7 \%$ ，郡部 $-5.6 \%$ となり，農村部から都市部への人口の移動をみ $亏^{31}$ 。

さらに都市間での人口增の差異にも特性がみられる。 第 1 に，地方の都市よりも，東京圈の都市の人口の伸び が大きい。20\% を超える急成長都市は，東北地方圈中 心の似台市周辺の 2 市を除くと，約 60 市が首都圈に集 中している。

第 2 の特性は，県庁所在地の優位性である。ことに首 都圏から離れる東北 6 県では, 地図上に県庁所在地を容 易に指摘できる。県庁所在地の人口増加率の単純平均は 87\% と，一般市部平均にくらべて高い。

第 3 の特性は，強力な工業化政策をとってきた地域の 伸びが大きいこと。首都圏一帯から弧立し，あるいは県 庁所在地以外で地図上に顕著にあらわれる八戸・石巻・ 郡山・鹿島・神栖等はいずれも工業化推進都市であ る。

なお東京区部人口の伸びが鈍り，周辺部で人口が増加 し，巨大な郊外化現象を示している゙)。

（2）人口密度（図4）市町村によって人口密度 の差異が非常に大きい。単純に 5 階級に分級して地図化
すると, 首都圈のみが強くあらわれ, 続いて地方圈の中 心仙台や青森・盛岡などの一部県庁所在地を指摘でき る。行政的に市町村の境界設定に個性があり，かならず しも共通規準として判断できないが, 東北 6 県の市部, 郡部の平均人口密度はそれぞれ $306.7,80.1$ 人 $/ \mathrm{km}^{2}$ と なり，都市・農村の差異は大きい5)。

とくに人口が集中している地区（DID 地区）の分布 をあわせてみると，首都圈はもちろんのこと，県庁所在 地である宇都宮・福島・仙台・盛岡・青森を結ぶ幹線沿 いに連続的に分布している ${ }^{6)}$ 。

（3）世帯人員（図 5)「都市化」の社会現象とし て小家族化傾向が話題になる。地図上でみても，農村部 の家族人員が大きく, 都市部のそれは小さい。東北 6 県 の市部平均 3.87 人, 郡部平均 4.55 人である。都市部 ・農村部ともに小家族化が進行しているが，この対比に 将来新たな局面が現われるかも知れない?。

小家族化傾向は，首都圈と,ともに，県庁所在地や工業 化都市に著しい。地図上に県庁所在地を指すことが可能 である。いっぽら首都圏や幹線から離れた山間部・海岸 部にも小家族化傾向が見られる。都市部への人口流出に よる過疎化が，家族人員の減少となってあらわれたもの といえるだろ ${ }^{8)}$ 。

（4）老齢化（図 6) 農村部から都市部にむか5 人口の移動は, 若い年齢層が、中心である。そのため農 村・都市双方の年踰別人口構成が変化する。農村部では 高齢者の割合が多くなる。逆に都市部では若年層が多く なり，さらにその年龄層が新しい家族で次の世代を育て るためこの傾向が助長される。年少人口（0 14 才）に たいする老齢人口（65 才以上）の比率老年化指数をみ よう。

特色の第 1 として，首都周辺の若年化が著しい。地方 から東京にむから人口流動の結果であることは，いらま でもないだらう。

特色の第 2 は, 幹線地帯から離れた山間部の老龄化の 傾向である。東北 6 県の山閒部の動向とともに, 首都圈 内の埼玉 ・千葉両県にも著しい老齢化地域の点在を指摘 できる。首都による直接的な人口吸引力によるものとし て注目される。

そのほか工業都市の若年化がみられる一方, 県打所在 地の特性は人口増加率や世帯人員ほどではない。むし 東京区部が周辺より老齢化が進行する郊外化現象が注目 される。以前憹村部にも若年層が多かったものが, 「都市化」にともなら人口移動によって農村部の老齢化, 都市部の若年化がす寸み，さらに今後は都市部の機能分 解によって都心の老跉化，郊外の若年化がすすむことが 予想される。

な押東北 6 祘での老年化指数の平均は, 市部で 14.6 $\%$ ，郡部で $31.6 \%$ である ${ }^{9}$ 。 


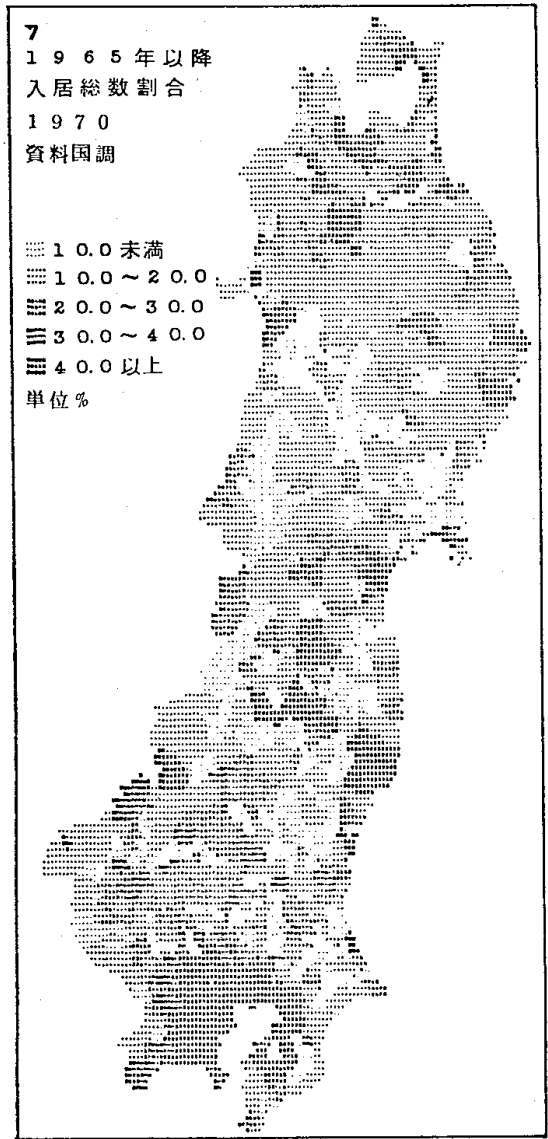

図-7

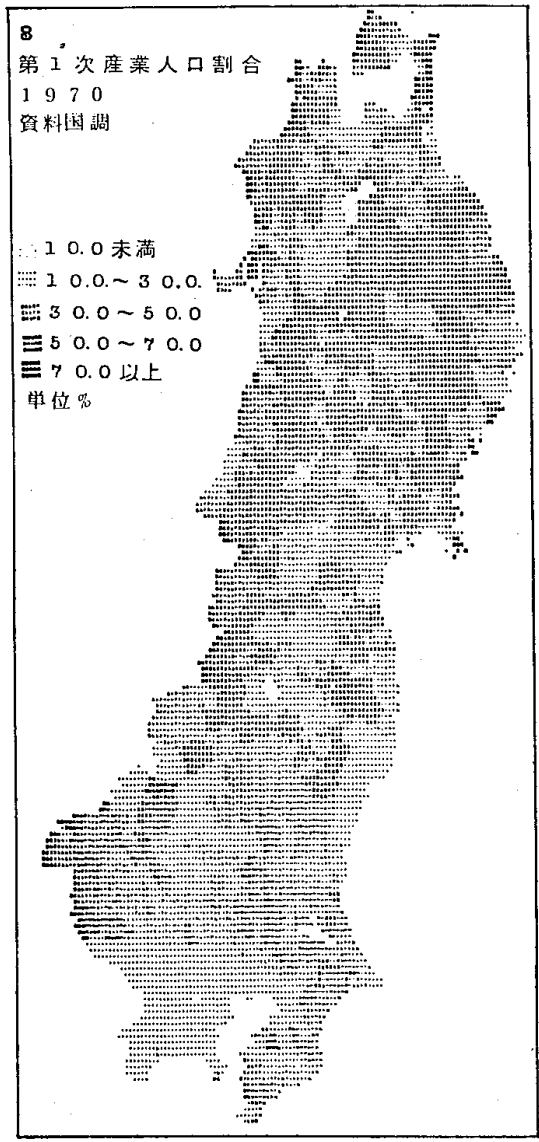

図一8

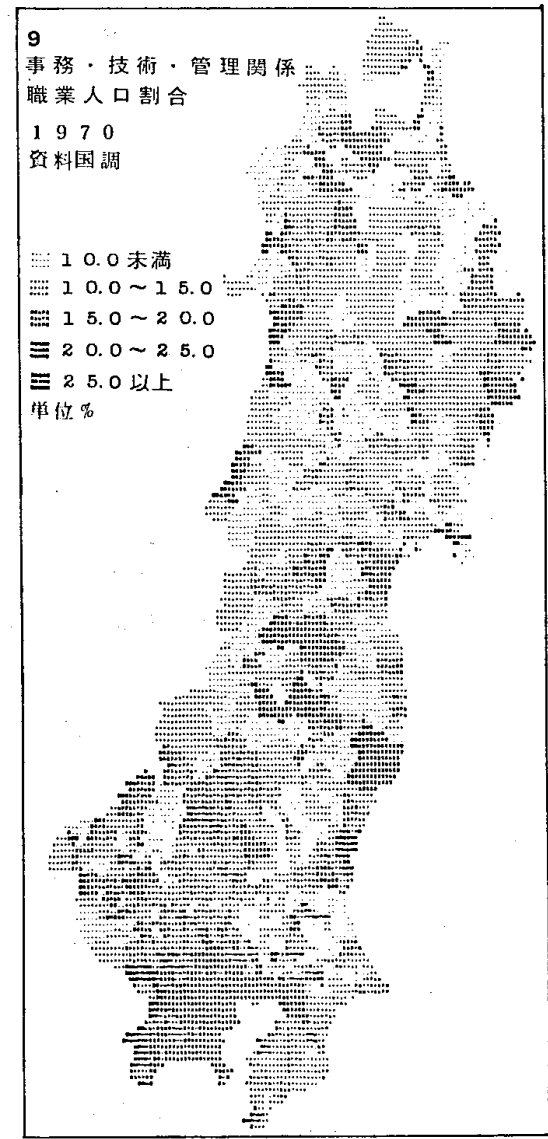

図一9

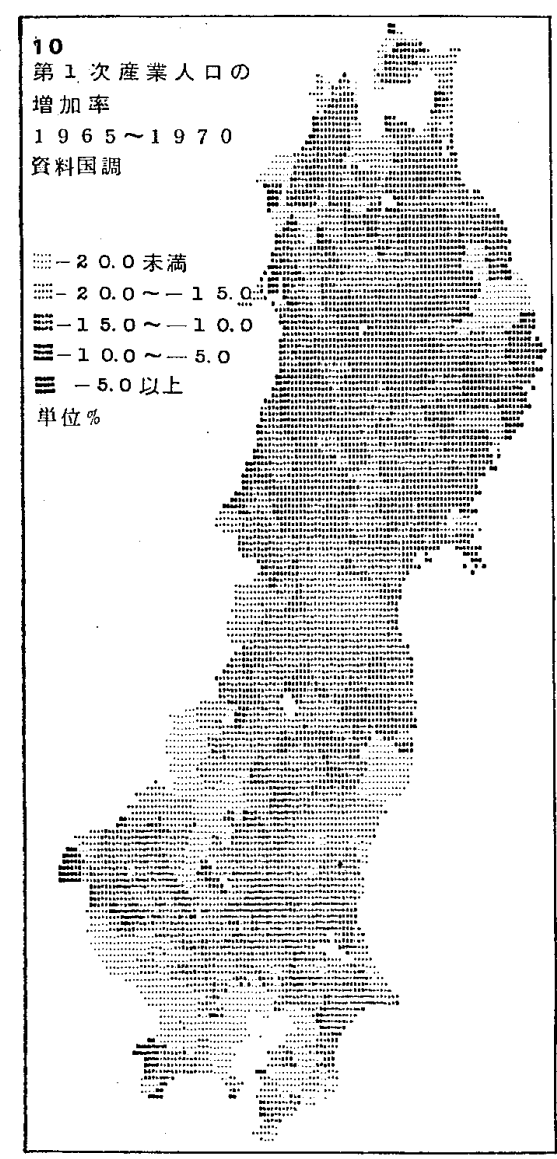

図-10

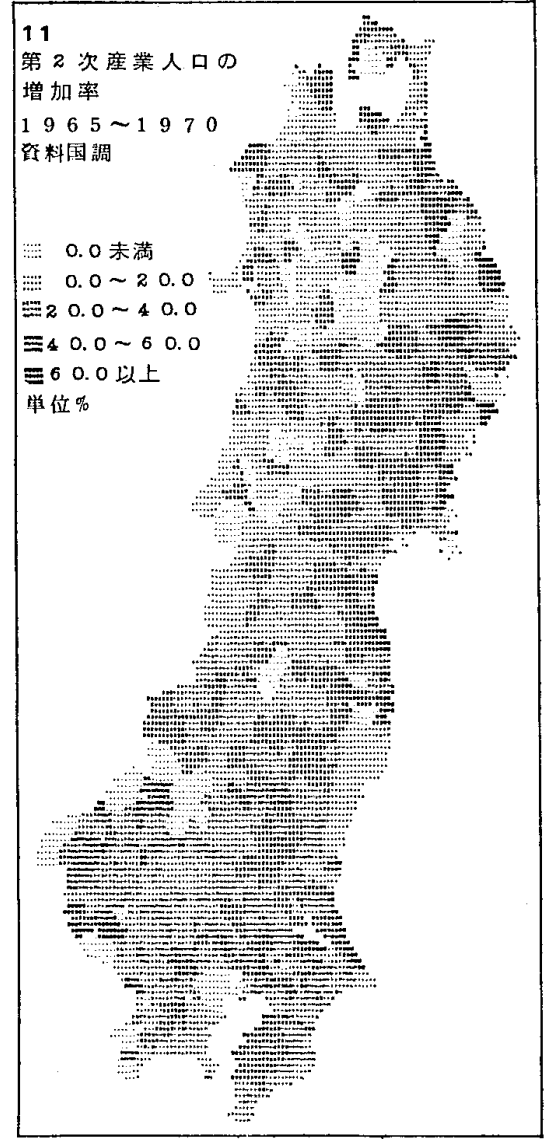

図-11

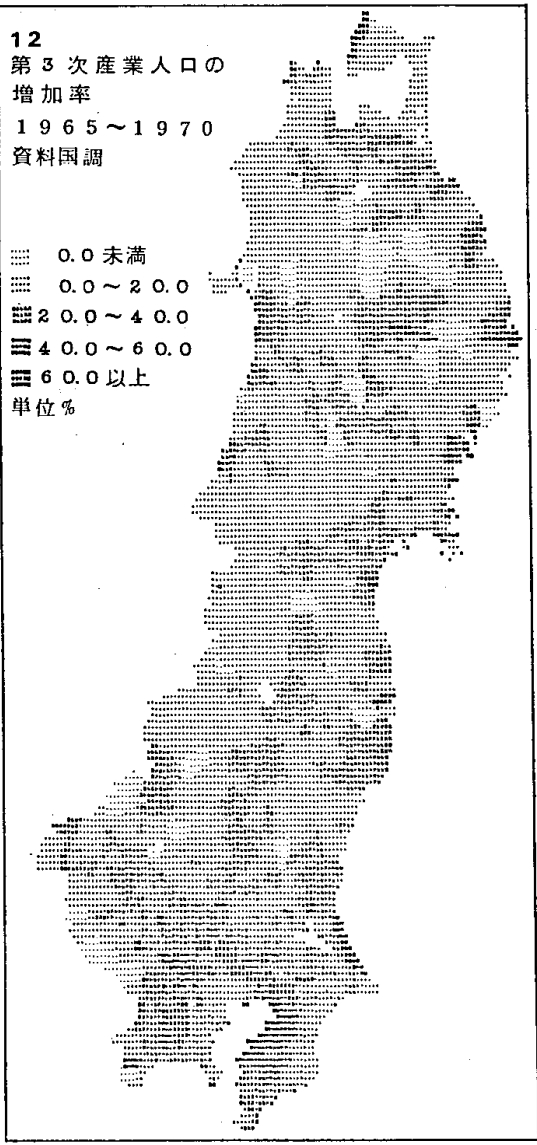

図-12 
（5）人口の移動（図 7) さきにみた人口の増加 率は，あくまで増加人口と減少人口の相殺結果であり， 域内転居を含めた人口の移動全体をあらすすものではな い。そこでそれを調べるために，1965 年以降 5 年間の 入居総数割合をみる。総人口にたいする入居者数の割合 である。「都市化」がすすむほど人口の移動がはげしく なるといら想定のもとに。

人口の増加率が大きかった首都圈や県庁所在地，工業 化都市に人口の移動が大きい。東北 6 県で市部・郡部の 平均入居総数の割合は，それぞれ $33.1,14.9 \%$ であり， 都市部の移動性が大きいことを示す。同じく県打所在地 の6市の単純平均をみると， $41.6 \%$ で，市部のなかで も高率である。

いっぽう人口増加率で急増を示さなかった山間農村部 の一部で大きな移動数值があらわれる。定住人口の減少 にともない移動性の影響が大きいものと思われる

（6）第 1 次産業人口割合（図 8 ） 主として農業・ 漁業を中心とした第 1 次産業に従事する人口の割合は， 「都市化」の進行にともなって減少する。いらまでもな く, その割合は農村部に大きく, 都市部に小さいことが 想定される。東北 6 県の平均值をみると, 郡部・市部で それぞれ $53.9,24.0 \%$ となっている ${ }^{11}$ 。地図上に地域 特性をみよう。

首都圏, 県庁所在地, 工業化都市でその割合が小さく なっている。首都圈の影響が北上する幹線網沿いにひろ がっている。製造・建設・運輸・販売を中心とした第 2 次・第 3 次産業への転換が，交通動脈との緊密なつなが りのうえに成立することを端的にあらわしている。

東北 6 県では，農村部に囲まれた県庁所在地を指摘で きる。それぞれの第 1 次産業人口割合の単純平均は $12.7 \%$ ，さきに示した市部平均をさらに下まわる。県庁 所在地の中核的な役割を産業棈造の側面からもうかがえ る。

いっぽう農村地帯ではほとんどの地域が $40 \%$ 以上の 人口割合になるが，一部山閒農村部でその比率が落ち, あたかも都市部のよらな構成比を示している ${ }^{12)}$ 。

（7）事務・技術・管理関係職業人口割合（図 9) 産業別人口から職業別人口に視点を移そら。4 群に大別 される職業人口のなかで，事務・技術・管理関係職業人 口のいわゆるホワイトカラーの割合が，「都市化」の進 行を明確にあらわすといわ和る ${ }^{13)}$ 。「都市化」がす寸む ほど，その人口割合が大きくなるといらものである。東 北 6 県について人口割合の平均值を算出すると，市部・ 郡部でそれぞれ 23.7, $11.5 \%$ となり, 想定が 裹付けられる。地図上に地域特性をみよう。

第 1 の特性は, 首都圈での大きい人口割合の ひろがりである。首都圈への集中度がよくあら われる。細部に注意するならば，首都圈の通勤
網にしたがって放射状に伸びていることも指摘できる。

第 2 の特性は, 周辺部にくらべて県仃所在地の割合が 大きいこと。関東・東北地方全域で, 県庁所在地を地図 上に指し示すことが可能である。ちなみに東北 6 県県打 所在地の単純平均人口割合は $32.3 \%$ になり, さきの市 部平均よりさらに高くなる。

第 3 の特性は, 県打所在地に準ずる地域中心都市や工 業都市の割合の高さ, 弘前 -八戸 (以上青森県), 北上水沢 (岩手県), 古川 (宮城県), 能代 - 横手 (秋田県), 鶴岡・酒田・米沢 (山形), 若松・郡山・ いわき（福島 県) 等の各市で，その多くは歴史的にも地域の中心的な 役割をはたしてきたものである。首都圏に隣接する茨 城・杤木・群馬の各県では, 県庁所在のみの割合が大き く, 首都圈の支配力の大きさがらかがえる14)。

（8）第 1 次産業人口の増加率（図 10）さきの第 1 次産業人口割合にたいし，その 5 年間（1965 70 年） の変動をみよう。最近よく指摘されるように, ほとんど の市町村で第 1 次産業人口が減少傾向にある。増加して いるのは対象 872 市町村のうち 25 町村, 約 $3 \%$ にす ぎない。

地域特性は，まず首都圈の減少。東京都はもちろん, 神奈川・千葉の各県にまで及んでいる。

関東・東北南部にくらべて, 青森・岩手・秋田と, 首 都圈から離れた東北北部 3 県は安定傾问にある。

ところでさきの第 1 次産業人口割合で地域特性を示し た県庁所在地は，この場合周辺部との差異はかならずし も大きくない。一部工業都市の減少傾向の方が著しい。 さらに注目すべきことは, 山間農村部の減少傾向で, 首 都圈に匹敵する数值である。ことに埼玉・東京・千葉の 山間・海岸部の減少率は, 首都圈の拡大部分と連続して しまっている ${ }^{15)}$ 。

（9）第 2 次産業人口増加率（図 11）建設・製造 業を中心とした第 2 次産業人口増加率の地域特性は, ま ずその分布状況に首都や県庁所在地の影響が汪とんどみ られないことである。東京区部では減少し，また多くの 県庁所在地では漸増程度にとどまっている。いわゆる工 業の地方分散を呈示しているといえるだるら。

いっぽう大都市以外では, 山間農村部の減少がある が，一部に急増傾向を示寸ところもあり，自治体による 政策選択の差異もあらわれている。工業化推進に歴史を 刻んできた千葉・川崎・釜石・八戸などでは郊外化, 周 辺化が進行して, 人口伸びは小さく, 新興の鹿島・神栖 なぞでは，500\% を超える激增を示している

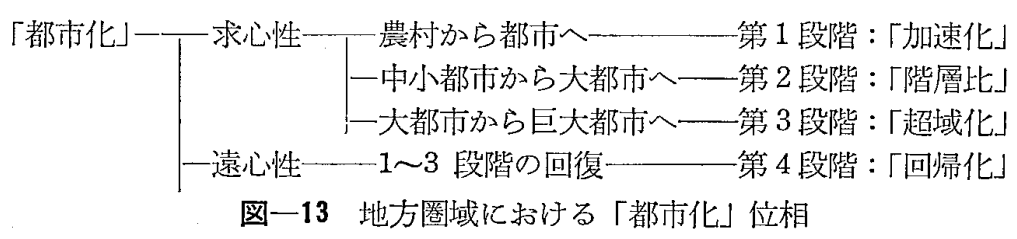


（10）第 3 次産業人口増加率（図 12）販壳・運輸 関倸の第 3 次産業人口の增加率をみよう。

全域的な漸増傾向がみられ，第 1 次产業人口の場合と 対照的である。目庁所在地とその周辺部に急増地域がひ ろがり，県庁所在地を地図上に指示することが可能であ る。さらに工業化都市や，首都圈加北上し仙台にいた る幹線沿いにも，急増地域が連なる。

首都圈では，東京区部を中心とした人口の郊外化によ って周辺部に激増地域がひろがり，都心を囲む。東京区 部は漸堌程度で，周辺部と対照を示している

以上産業別人口増加率を通しての地域特性を整理しょ う。まずいずれの指標も人口増加率（全体）との相関性 が強いことである。ことに第 3 次産業人口に顕著であ り，第 2 次産業人口については，首都圈にその傾向がみ られる。山閒部の減少も全体人口増加率との関連性が強 いが，第 2 次産業人口については，逆に急増地域す存在 する。

第 2 に, 首都圏, 県庁所在地の影響が大きいのは, 第 1 次産業人口増加率である。第 3 次産業人口がこれに準 ずる。いうまでもなく，第1 次産業人口は減少し，第 3 次のそれ㴔增傾向にある。ただ第 2 次，第 3 次産業人 口ともに，東京区部や県庁所在地では変化が小さい。

「都市化」にともなら地域変動が，これら大都市圈から その周辺部や，地方に移行しつつあると結論づけること ができるだろう。

\section{3.「都市化」位相の設定}

以上人口指標を地図化しての地域特性の解析から, 都 市部の主導性による地域変動, 寸なわち「都市化」の空 間構造が，都市中心の変動である「求心性」から，都市 より地方に変化が大きい「遠心性」まで展開しているの をみた。「都市化」の力学運動的な周期性が注目される。

そこで地方圈域における「都市化」の変動位相をつぎ の 4 段階に設定し，指標ごとに分析してきた地域特性を 整理しよう (図 13 参照)。

（1）地方圏域「都市化」の第 1 段階：「加速化」

地域の性格が, 農村的なものから都市的なものへと变 化していく「都市化」こ㞦が種々の要因によって部分 的に加速され，都市・農村間の差異を搪大寸る。「都市 化」の初期段階として「加速化」とよぶ。「加速化」は 人口指標のほぼすべてに顕著にあらわれている。その主 なる要因として，地域が位置的には幹線沿いまたは巨大 都市圈に含まれること, 徂打所在地または工業化都市で あることが考えられる。

（2）地方圈域「都市化」の第 2 段階：「階層化」

農村部から都市部への「加速化」がさらに進行し, 都 市間に競合がおこりそそれぞれの間に序列化がすすむ。 第 2 段階としての「階層化」である。県庁所在地や地方 圈の中心都市（仙台のように）が優位を占め, 日常生活
圈の中心となる中小都市を支配する。これは人口増加 率, 人口移動, 事務・技術 - 管理関係職業人口割合等で 注目された。

（3）地方圈域「都市化」の第 3 段階：「超域化」

都市間の「階層化」がさらに進行し, 県または地方圏 レベルの大都市を支配する，巨大都市圈が形成される。 その圈域には数多くの市町村が包含され，影響力は日常 生活圈をはるかに超える。第 3 段階としての「超域化」 である。首都圈にもっともよく代表され，地方圈の中心 都市にもこの性格がみられる。人口増加率（とくに 20 年間の)，人口移動，第 1 次産業人口割合，事務・技術 ・管理関係職業人口割合等によくあらわれる。関東東北 地方の都県別人口の 20 年間の変化を追うと, 首都東京 一の人口集中から郊外化，さらには地方の人口増回復ま で，首都圏を基軸にした変動が顕在化する。

（4）地方圈域「都市化」の第 4 段階:「回归化」

都市部の，それも大都市・巨大都市の主導性による地 域全体の変化が逆流し，地方での地域変動の方が大きく なる。人口指標では第 2 次産業人口増加率にもつともよ くあらわれた。「加速化」にはじまった地域間の力学的 な運動は地域の再編にむかう。これを「回帰化」とよぼ う。まず首都では地域的な機能分解により，人口（若年 人口, 第 2 次・第 3 次産業人口を含めて) の郊外化がす すむ。地方圈の中心都市（仙台）の地位も定着してく る。その一方で, 本来なら農村的性格を保持しらると思 われる一部山間部でも「都市化」の影響により急激な地 域変動を経て，世帯人員・人口の移動等の指標では，む しろ都市的な值を示すようになる。

\section{注}

1) われわれの生活圏域は，その行動圏・影響圏によって何 段階にも構成される。今回研究対象の地方圈域は, 拡大 している生活圈のなかでももっとも広域的なものと位置 づける。社会・経済的な関連性は，長時間間隔であらわ れ，行政的には数県をあるせた範囲である。

2）「都市化」指標には基礎的な 3 群の結果的存在ともいえる 第 4 群社会指標がある。犯罪・事故・疫病・社会問題な ど，地域特性分析には欠ふなない側面である。

3）全国平均 5.5 , 市部 8.7 , 郡部 $-1.9 \%$ 。

4）増加率別市町村数分布は，ほぼ正規分布を示す。

5）全国平均 280.3 , 市部 791.0 , 郡部 105.3 人 $/ \mathrm{km}^{2}$ 。

6）密度別市町村数分布をみると，地域間の差異が大きく， $1.0 \sim 30$ 人 $/ \mathrm{km}^{2}$ の市町村がもっとも多い。

7) 全国平均 3.69 , 市部 3.54 , 郡部 4.12 人/户。

8）人員別市町村数分布は，なめらかな正規分布。

9）指数別市町村数分布は，なめらかな正規分布。なお全国 平均の老年化指数は $29.6 \%$ 。

10）大居割合別市町村数分布では，10\% 前後を頂部に市町村 が集中する。

11）全国平均 19.3 ，市部 10.4 ，郡部 $40.9 \%$ 。

12）割合別市町村数分布では，1林台から $80 \%$ までひろく分 布しており，5\% 前後に都市部の頂点が，45〜60\% に農 村部の頂点がタられる。

13）地理学者ゴットマンが，都市の「メガロポリス化」の過 程でホワイトカラー人口増加を゙指適していることに符合 する。 
14）人口割合別市町村数分布では，10\%最大值に典型的な 正規分布定示卞。都市の階層性として注目される。

15）増加率別市町村数分布では，-11〜－13\%を頂部に咶ぼ 正規分布宗示与。
16）增加率別市町村数分布では，10〜50\% 間にほとえどが集 中学る。

17）増加率別市町村数分布では，10〜30\% 閒に汪とんどが集 中する。

\title{
S Y NOPSIS
}

U.D.C.711.3.011.1

\section{SPATIAL STRUCTURE OF URBANIZATION IN KANTO-TOHOKU DISTRICT OF JAPAN}

\author{
[1. Variables on Population] \\ by SHIRO AOKI and YOSHIRO YAMAMURA Members of A.I.J.
}

The purpose of this report is to analize the spatial structure of urbanization in Kanto-Tohoku district of Japan. This district has an area of $99176 \mathrm{~km}^{2}$ and a population 42000000 . The study covered such variables on pupulation as :

Population change, 1965-70,

Density of population (per. sq. kilometer),

persons per households,

ratio of aged population 65 and over to children under $15(\%)$,

$\%$ of population by time of last move after 1965 ,

$\%$ in primary industry,

$\%$ in white-collar, professional and managerial occupation,

Rate of increase from 1965 to 70 in primary industry,

Rate of increase from 1965 to 70 in secondary industry,

Rate increase from 1965 to 70 in tertiary industry.

As a result, these variables are commonly related to the following phases of urbanization:

Stage 1. Acceleration from rural side to urban side,

Stage 2. Class organization by conflicts between cities,

Stage 3. Extra-regionalization by influence of metropolis,

Stage 4. Regression (i.e. decentralization, deconcentralization and reorganization of regional structure). 